\title{
Recent uplift of the Atlantic Atlas (offshore West Morocco): Tectonic arch and submarine terraces
}

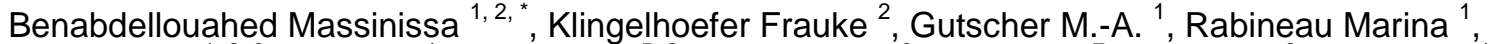 \\ Biari Youssef ${ }^{1,2,3}$, Hafid M. ${ }^{4}$, Duarte J.C. ${ }^{5,6}$, Schnabel M. ${ }^{6}$, Baltzer A. ${ }^{7}$, Pedoja K. ${ }^{8}$, Le Roy P. ${ }^{1}$, \\ Reichert C. ${ }^{6}$, Sahabi M. ${ }^{3,9}$
}

${ }^{1}$ Laboratoire Géosciences Océan, UMR6538, IUEM, rue Dumont Durville, 29280 Plouzané, France

2 Ifremer, Dept. Marine Geosciences, ZI de la Pointe du Diable, CS10070, 29280 Plouzané, France

${ }^{3}$ Université Chouaïb Doukkali, Faculté Des Sciences, Laboratoire Géosciences Marines et Sciences des sols - URAC 45, BP 20, 24000 El Jadida, Morocco

${ }^{4}$ Laboratoire de Géophysique et d'Environnement, Département de Géologie, Faculté des Sciences, BP 133, Kénitra, Morocco

${ }^{5}$ Instituto Dom Luiz and Departamento de Geologia, Universidade de Lisboa, Campo Grande, 1749-016 Lisboa, Portugal

${ }^{6}$ School of Earth, Atmosphere \& Environment, Monash University, Clayton, Melbourne, VIC 3800,

Australia

${ }^{7}$ Bundesanstalt fuer Geowissenschaften und Rohstoffe (BGR), Geozentrum Hannover, Stilleweg 2,

30655 Hannover, Germany

${ }^{8}$ Laboratoire Géolittomer, CNRS-UMR 6554 LETG, Université de Nantes, 44312 Nantes Cédex 3 , France

${ }^{9}$ University of UCBN Caen CNRS, UMR 6143 M2C, F-14000 Caen, France

* Corresponding author: Massinissa Benabdellouahed, email address :

massinissa.benabdellouahed@univ-brest.fr

\begin{abstract}
:
Re-examination of marine geophysical data from the continental margin of West Morocco reveals a broad zone characterized by deformation, active faults and updoming offshore the High Atlas (Morocco margin), situated next to the Tafelney Plateau. Both seismic reflection and swath-bathymetric data, acquired during Mirror marine geophysical survey in 2011, indicate recent uplift of the margin including uplift of the basement.
\end{abstract}

This deformation, which we propose to name the Atlantic Atlas tectonic arch, is interpreted to result largely through uplift of the basement, which originated during the Central Atlantic rifting stage - or even during phases of Hercynian deformation. This has produced a large number of closely spaced normal and reverse faults, "piano key faults", originating from the basement and affecting the entire sedimentary sequence, as well as the seafloor.

The presence of four terraces in the Essaouira canyon system at about $3500 \mathrm{~m}$ water depth and "piano key faults" and the fact that these also affect the seafloor, indicate that the Atlantic Atlas is still active 
north of Agadir canyon.

We propose that recent uplift is causing morphogenesis of four terraces in the Essaouira canyon system. In this paper the role of both Canary plume migration and ongoing convergence between the African and Eurasian plates in the formation of the Atlantic Atlas are discussed as possibilities to explain the presence of a tectonic arch in the region. The process of reactivation of passive margins is still not well understood. The region north of Agadir canyon represents a key area to better understand this process.

\section{Highlights}

A tectonic arch called "Atlantic Atlas" has been identified offshore the High Atlas. The Atlantic Atlas is still active. Four submarine terraces are identifiable in Atlantic Atlas (offshore Essaouira). The recent uplift is causing morphogenesis of four terraces.

Keywords : Atlas Mountain belt, Tectonic arch, Moroccan passive margin, Submerged terraces, Uplift 


\section{Introduction}

The Atlas Mountain belt of North Africa is one of the largest intra-continental mountain belts in the world. The Atlas Mountains extend from the Atlantic Ocean near the Canary Islands along the NW edge of the African craton just south of the active Africa-Eurasia plate boundary, expressed by the Alpine collisional belt (Frizon de Lamotte et al., 2009; Hafid et al., 2006; Michard et al., 2008). The Western High Atlas is the western limit of the Atlas Mountains (Fig. 1a) and represents the highest segment of the Atlas system where several peaks surpass $4000 \mathrm{~m}$ elevation (J. Toubkal, $4167 \mathrm{~m}$ ) (Missenard et al., 2008). The Atlas Mountains cross NW Africa along a WSW-ENE trend from the Atlantic Ocean to the Tunisian Mediterranean coast over a length of about $2000 \mathrm{~km}$ (800 km in Morocco) and a width ranging from about $50 \mathrm{~km}$ to $100 \mathrm{~km}$. They form the boundary between the Meseta domains (Morocco Meseta and High Plateaus) to the north, and the West African Craton (Anti-Atlas belt) to the south (Fig. 1a). The Atlas mountains, which represent the southernmost element of the peri-Mediterranean Alpine belts, are considered to be a typical intracontinental belt (Frizon de Lamotte et al., 2009; Mattauer et al., 1977). They formed within the African (Nubian) plate as a result of the convergence between Africa and Eurasia during the Cenozoic (Dewey et al., 1989; Gomez et al., 2000). However, in contrast with the Alpine-type collisional Rif belt and Tell domain, the Atlas system developed over a continental crust that was only slightly thinned during its pre-orogenic evolution (Frizon de Lamotte et al., 2008; Missenard et al., 2006). The southern boundary of the Atlas is marked by the South Atlas Fault Zone (Russo and Russo, 1934), which extends from Morocco (where the High Atlas belt is juxtaposed to the Anti Atlas) to Tunisia (Bracene et al., 1998). Strike slip movement along the ENE-WSW trending South Atlas fault was proposed to be the cause of the destructive 1960 Agadir earthquake (Medina and Cherkaoui, 1988). The focal mechanism indicating WNW-ESE compression is in good agreement with the orientation of the ongoing Africa-Eurasia convergence. 
The High and Middle Atlas form an intraplate orogen, uplifted during the Cenozoic by a combination of lithospheric thinning and crustal shortening (Missenard et al., 2006). According to (Frizon de Lamotte et al., 2008, 2009), the tectonic-driven Cenozoic uplift began around the time of the Eocene-Oligocene limit. Numerous authors, on the basis of structural geological analysis (balanced cross-sections) (Frizon de Lamotte et al., 2009) and analysis of geoid, topography and gravimetric anomalies ( Teixell et al., 2005; Fullea Urchulutegui et al., 2006; Missenard et al., 2006; Fullea et al., 2007; 2010) conclude that the modest crustal thickening observed beneath the Atlas mountains is insufficient to explain their high topography. Indeed these workers conclude that the NE-SW trending zone of anomalously high topography spanning through the Anti-Atlas, the High Atlas and Middle Atlas is associated with a substantial thinning of the lithosphere to values of around $80 \mathrm{~km}$ (Fullea et al., 2010, 2007). More recently, the use of resistivity methods (Anahnah et al., 2012) and passive seismological studies using receiver function analysis (Miller and Becker, 2014; Spieker et al., 2014) have also concluded that there is only modest crustal thickening and unusually thin lithosphere beneath the Atlas Mountains. Several authors suggested a Cenozoic tectonic inversion in the evolution of the High Atlas system (Beauchamp et al., 1999; Hafid, 2000; Laville and Piqué, 1992). This Plio-Quaternary uplift of the Moroccan High Atlas resulted in uplift of coastal marine terraces (Pedoja et al., 2014) and fluvial incision (Boulton et al., 2014).

The Atlas Mountains region experienced widespread volcanism during the Cenozoic. This volcanism can be divided into two phases: the first pulse started at the beginning of the Cenozoic and the second, more intense phase, with higher volumes of volcanic products, occurred around $11 \mathrm{Ma}$ in the Miocene (Missenard et al., 2006). Quaternary volcanism, primarily in the form of alkali basalts, affects the Anti-Atlas, the High and the Middle Atlas and extends to the Mediterranean coast of the Rif (Bosch et al., 2014; El Azzouzi et al., 2010). 
Geochemical analysis of lavas from the Canary Islands and from the Middle Atlas and the Western Mediterranean region indicate an affinity between the Canary-like geochemistry and the sub-continental corridor of shallow lithosphere-asthenosphere boundary (Duggen et al., 2009). These authors propose that Canary mantle plume material flowed laterally beneath northwest Africa through a lithospheric corridor (following the strike of the Atlas Mountains), causing continental intraplate volcanism above it. This flow of plume material is also in good agreement with the anomalously low seismic mantle velocities recorded underneath the Atlas Mountains and is offered as an explanation for the uplift of the Atlas mountain range (dynamic topography). Another possible explanation for this flow could be mantle dynamics related to the roll-back of the Gibraltar subduction zone (Gutscher et al., 2002; 2012). A portion of the Canary plume may have been captured by the toroidal mantle flow around the Gibraltar slab, a mechanism recently demonstrated by lithosphere-asthenosphere-scale analogue models (Mériaux et al., 2015). Evidence for this toroidal flow is offered by observations of anisotropy in the upper mantle from analysis of fast directions from SKS wave splitting (Diaz et al., 2010).

Directly north of the Canary Islands a region of thickened oceanic crust was imaged using reflection and wide-angle seismic data. The thickening of the underlying oceanic crust is interpreted to be the result of underplating and assimilation of existing oceanic crust caused by the Canary thermal anomaly (Holik et al., 1991) and related to the passage of the Canary Hotspot, which would have caused local uplift and volcanism (Carracedo et al., 1998; Holik et al., 1991). Based on the different of ages for a major hiatus in DSDP drill sites 415 and 416 and deep seismic data, it was recently proposed that this passage led to the successive reactivation of oceanic basement faults/fractures from the north to the south (Neumaier et al., 2015).

The Tafelney Plateau is a prominent basement high, located offshore Essaouira in the continuity of the High Atlas system and a link between the mountain range and this 
submerged relief feature has been proposed, where the plateau would represent the offshore extension of the High Atlas mountains (Hafid et al., 2000). The Tafelney Plateau has also been interpreted as a transfer zone where the rifting style and asymmetry change from south to the north (Louden et al., 2013; Tari and Molnar, 2005). According to this interpretation the northern Canadian margin and the southern Moroccan margin would both be lower plate margins and the northern Moroccan and southern Canadian margin would represent the corresponding upper plate margins (Tari and Molnar, 2005).

In the present study, the dataset acquired offshore Safi during the MIRROR marine geophysical survey (2011) including deep, and high-resolution seismic data combined with bathymetric data, provide new images to determine the architecture of the seaward termination of the Atlas Mountain system and the lithosphere-asthenosphere boundary corridor. The objective of this work is to provide new insights to address the questions of the effects of the regional uplift on the seabed, the influence of the passage of the Canary Hotspot in the region and the offshore prolongation of the Atlas mountain belt.

\section{Structural setting}

The Atlantic margin of Morocco extends over nearly 3000 km in NW Africa (Fig. 1) (Tari and Jabour, 2013). The surveyed Agadir-Essaouira or Tafelney Plateau segment is located to the south of the Seine Basin offshore the city of Essaouira (Fig.1).

The Atlantic Moroccan margin is composed of several structural domains such as the external Rif, the Meseta, the High Atlas and the Anti-Atlas that overprint or interfere with the structures that resulted from the opening of the Atlantic Ocean (Frizon de Lamotte et al., 2009). This margin has experienced a comparable evolution along its entire length, marked by rifting phase during late Triassic to Early Jurassic followed by seafloor spreading that initiated around 180-170 Ma (Davison, 2005; Sahabi et al., 2004). However, the sedimentary cover of 
the Agadir-Essaouira segment and the Tafelney Plateau shows a deformed structural trend compatible with those of the High Atlas (Haddou and Tari, 2007).

The structure and stratigraphy of this segment of the African margin has been described in considerable detail (Hafid, 2000; Hafid et al., 2006; Le Roy et al., 2004, 1998; Ruellan and Auzende, 1985; Vincent et al., 1980), and appears to be generally similar to that of the entire NW African Atlantic margin, with Triassic red bed rift infill, followed by Early Jurassic salt, Jurassic to Early Cretaceous carbonate platforms, and a marine clastic infill during the Cretaceous and Tertiary (Davison, 2005).

The Late Triassic to Early Jurassic salt bodies were deposited during the last stages of rifting prior to the continental break-up (Hafid, 2000). The salt domes identified in the multi-channel seismic data (Haddou and Tari, 2007; Hafid et al., 2008; Tari and Jabour, 2013) show characteristic halokinetic elements of a passive margin, such as translation salt structures underneath the shelf and the slope. All identifiable salt structures are located to the east of magnetic anomaly S1 (Fig. 1a) (Biari et al., 2015; Contrucci et al., 2004; Sahabi et al., 2004). In this area the basement corresponds to the western prolongation of the Paleozoic basement of the Hercynian western Meseta, which has remained relatively stable since the Upper Triassic to Lower Liassic rifting of the central Atlantic Ocean (Le Roy and Piqué, 2001; Sahabi et al., 2004). According to (Hafid et al., 2000), there is a structural and stratigraphic continuity between the inland western termination of the Atlas and its corresponding offshore domain. The difference between the onshore and offshore is thought to be an expression of different lithospheric properties (Biari et al., 2015; Hafid et al., 2000).

\section{Data}

During the Mirror marine seismic survey carried out in 2011, seven coincident multi-channel, high-resolution sub-bottom and wide-angle seismic profiles were acquired in order to image the sedimentary and crustal structure of the Moroccan Margin. All multi-channel seismic 
profiles were acquired with the R/V L'Atalante, using a tuned airgun array of $7591 \mathrm{in}^{3}$ and a 360-channel digital seismic streamer. The results of modelling of the wide-angle seismic data were recently published (Biari et al., 2015; Klingelhoefer et al., 2015). The multi-channel seismic data were processed using Promax and Geovecteur software packages in order to image sedimentary and crustal structures. The data were interpreted using the Kingdom Suite Software and integrated into ArcGIS 10.2 software.

Additional high-resolution sub-bottom seismic data were acquired along all profiles using the hull-mounted high-resolution sub-bottom profiler of the R/V Atalante. The profiler works with frequencies between 1.8 and $5.3 \mathrm{kHz}$, which allows for vertical resolutions of about $\sim 30$ $\mathrm{cm}$. The bathymetric and high-resolution sub-bottom profile data thus allowed detailed imaging of the seafloor morphology and its internal sedimentary in the first several hundred milliseconds TWTT below the seafloor.

Bathymetric and reflectivity data were acquired using a Kongsberg EM122 and EM710 multibeam echosounder, operating at a main frequency of $12 \mathrm{kHz}$, which is the typical value for marine environments between 100 to 10,000 meters water depth (mwd). The data were processed and gridded using the Caraibes software and the resulting bathymetric map is presented with a $50 \mathrm{~m}$ grid cell size and the relative precision of the bathymetric data is $0.5 \%$. This map revealed many submarine landforms of the Moroccan margin offshore Safi. Additional existing reflection seismic data from the Bundesanstalt fuer Geowissenschaften und Rohstoffe (BGR) (Roeser et al., 2002) and the University of Texas (Holik et al., 1991) were used to complete a broader, regional picture.

\section{Results}

\subsection{Bathymetry of the Moroccan margin off the High Atlas mountain belt}

The study area is located on the continental slope and the basin offshore Safi at a water depth between $500 \mathrm{~m}$ and $4000 \mathrm{~m}$ (Fig. 1a). Three zones can be distinguished. The first zone (zone 
1, Fig 1b) corresponds to the continental slope with numerous canyons and channels dissecting the slope between 500 to 4000 mwd. The orientation of the canyons and channels varies from ESE-WNW to SE-NW (Fig. 1b). The second zone (zone 2, Fig. 1b) exhibits a relatively flat seafloor at $4000 \mathrm{mwd}$ (Fig. 1b). This flat basin corresponds to a segment of the Seine abyssal plain (SAP), which is located offshore of the Moroccan Meseta. The third area represents a prominent positive bathymetric feature that forms a large-scale morphologic bulge of the seafloor. This approximately $100 \mathrm{~km}$ wide feature is located in the westernmost part of the study area between the volcanic Essaouira Seamount (to the West) and the continental shelf (to the East) and rises to about 3200 mwd (Fig. 1b). The bulge is bordered southward by the Agadir canyon and to the north by the Seine Abyssal Plain (Fig. 1a). From the bathymetric images it is possible to observe that the surface of this morphologic high is undulated showing a NE-SW fabric.

\subsection{High-resolution seismic (Chirp) profiles}

This focus area of this study is about $100 \mathrm{~km}$ long from the shelf break at a water depth of 120 to $150 \mathrm{~m}$ to the mouth of the canyon, measured along the axial channel. This area displays a relatively smooth seafloor. The canyon has a maximum rim-to-rim width of $5 \mathrm{~km}$ (Fig. 2a). The morphology of the Essaouira Canyon System banks shows strong variations. The east bank of the axial channel is bordered by the continental slope, while the west bank is characterized by the presence of several terraces (Fig. 2a). Four submarine terraces can be identified downslope at about 3,500 mwd (Figs. 7, 8). These flat surfaces bounded by scarps, are located among canyon levees. Submarine terrace sequences (T1, T2, T3 and T4) correspond to flat surfaces from 2 to $15 \mathrm{~km}$ long, with scarps at about the $75 \mathrm{~m}$ level.

The geometry of these steps suggests that the scarps are the truncated edge of horizontal beds, indicating that these are erosional rather than depositional features. The scarps that separate the staircase terraces (Fig. 2a) are often preserved from erosion and are prominent on the 
seismic profiles. The scarps are about $75 \mathrm{~m}$ in height (Fig. 2a) and at least four steps or terraces are identifiable. These terraces have developed towards the east. The oldest (T1) is located in the highest part of the bulge (or arch) about $40 \mathrm{~km}$ from the slope break, the second terrace is "T2", the third terrace is "T3" and the youngest (T4) is located near the current channel in the lowermost part of the canyon system, downslope (Fig. 2a).

The oldest terrace "T1" is about $15 \mathrm{~km}$ wide. In this terrace an incision is still preserved as evidence of the existence of palaeo-canyons. The second terrace "T2" is also preserved but without any clear incision. The third terrace "T3" almost preserves the canyon's flank shape with a concave bottom shape, about $6 \mathrm{~km}$ long. The morphology of the youngest terrace "T4" is similar to the second terrace. In total, an approximately $50 \mathrm{~km}$ wide sequence of incisions has been imaged by the high-resolution sub-bottom profiles (Fig. 2a). 


\subsection{Multichannel seismic data}

Multichannel seismic profiles were examined to better understand the origin and age of the terraces. Profile Mirror 01 (Fig. 2b) strikes along the higher-resolution seismic profile in the region of the terraces (see location, Fig. 1b). Similar stratigraphic interpretations of this area have been documented in earlier work ( Price, 1980; Ruellan and Auzende, 1985; Khatib et al., 1995; Hafid et al., 2008, 2006, 2000; Tari and Jabour, 2013). The profiles show about four high-amplitude horizons (Fig. 2b). The deepest corresponds to the top of the acoustic basement located between 7 and $8 \mathrm{~s}$ TWT. In the eastern segment of the profile, near the continental slope, the first $100 \mathrm{~km}$ of the top of basement is relatively flat and smooth, while further west it has a "roughness" typical of normal oceanic crust. In the eastern part of the profile, the deepest reflectors onlap onto the basement (Fig. 2b). According to (Price, 1980), this onlap is laterally equivalent to the top of the Triassic evaporites and is interpreted to represent the "break-up" event at this section of the continental margin. Regionally, this is a reflector which onlaps the Oxfordian oceanic basement to the west (Lancelot and Winterer, 1980). The horizon shown in red corresponds to the base of the Paleocene. Finally, the interval between this horizon and the sea floor corresponds to the upper Cenozoic (Tari and Jabour, 2013).

Both the horizon of the top of the basement and seafloor horizon are roughly parallel, as identified in the seismic profile (Fig. 2b and 3). This seismic profile also shows a number of closely spaced normal-faults, with a throw of over $150 \mathrm{~m}$, which could be interpreted as "piano key faults" (Fig. 3), cross-cutting the complete sedimentary sequence. Fault spacing is roughly $2 \mathrm{~km}$ with throw varying between several tens and up to $100 \mathrm{~m}$. The extent of the arch or bulge was mapped using reflection seismic data from Mirror (2011), BGR and the University of Texas (Holik et al., 1991) (Fig. 4). Indeed, profiles M203-14, M203-12 and M203-11 show parts of the arch. However, profile RC25-05-366A (Fig. 4) located in the 
Agadir canyon region shows no basement arch. The southernmost profile RC25-05_364B (Fig. 4) images a basement and seafloor arch, only slightly affected by normal faulting on one of its flanks.

We verified using the seismic profiles processed in depth (Fig.5) and the wide-angle seismic models (Fig.6) that the basement bulge exists in depth as well and is not simply a pull-up effect caused by p-wave velocity variations in the sedimentary layers.

To the south this arch or bulge is bounded by the Agadir canyon (Fig. 4), which seems to be controlled by a major NW-SE fault that extends from the southern boundary of the High Atlas, between $30^{\circ} \mathrm{N}$ and $10^{\circ} \mathrm{W}$ to $33^{\circ} \mathrm{N}$ and $12^{\circ} \mathrm{W}$ (Fig. 8).

\section{Discussion: Submarine terraces and tectonic arch of the Atlantic Atlas}

Above, in this paper two different wordings have been used, bulge and arch. Numerous authors (Holik et al., 1991; Patriat and Labails, 2006) observed a bathymetric swell north of the Canary Islands and proposed this to be a bulge and its cause to be the effect of a hot spot drifting toward the South. According to Tari and Jabour, (2013) the uplift and neotectonic arching has affected the Tafelney Plateau and Atlas Mountains. Hereafter, in this paper we prefer to use the term tectonic arch to discuss the origin of the swell morphology shown in the figure 2 because, the seismic reflection and swath-bathymetric data reveal a relationship between tectonics and this swell morphology (Fig. 3). This deformation, which we propose to name the Atlantic Atlas tectonic arch, is interpreted to result from the uplift of the basement. The staircase sequence of submarine terraces identified at the mouth of the Essaouira Canyon is located at about 3500 mwd (Fig. 7), and therefore it could not have been affected by Quaternary sea level changes.

These terraces most likely correspond to inner terraces within a canyon system recording different periods of the activity. Sinuous deep-sea channels often display stepped intrachannel terraces also called inner terraces within canyons and deep-sea turbiditic valleys in e.g. the 
Zaïre canyon ( Savoye et al., 2000; Babonneau et al., 2002), in the Cap Breton canyon (Cirac et al., 2001; Mulder et al., 2012); in the Bengal and the Indus fan (Wynn et al., 2007) or Timiris canyon (Antobreh and Krastel, 2006). The terrace of the Essaouira canyon seems to record the activity of palaeo-canyons. Axial troughs and uplifted canyons are partially or completely eroded and only the erosional benches are preserved and organized into four staircase sequence terraces. The flat geometry of these terraces might be related to erosion by bottom and downslope currents (Fig. 7). Such flat terrace morphology can be interpreted as analogues of fluvial terraces.

The submarine channels/canyons are often compared to fluvial channels because of their similar shape (Flood and Damuth, 1987; Wynn et al., 2007; Chiang et al., 2012). Terraces are widespread geomorphic markers on land (marine terrace and fluvial terrace). Fluvial channels have been widely investigated, including studies of deformed areas with active subsidence or uplift in drainage basins (Bridge and Leeder, 1979; Holbrook and Schumm, 1999). Fluvial terraces can form on the one hand, in response to climate change (Blum and Törnqvist, 2000; Gibbard and Lewin, 2009; Lewin and Gibbard, 2010) and on the other hand due to tectonic uplift and drainage initiation (Bridgland and Westaway, 2012; Benabdellouahed et al., 2013). In the offshore domain, sinuous channels often display stepped intrachannel terraces (Wynn et al., 2007). These may form through a variety of processes, including multiple phases of channel incision and channel margin slumping (Deptuck et al., 2003; Baztan et al., 2005; Antobreh and Krastel, 2006; Duarte et al., 2010).

The Essaouira Canyon has a relatively straight morphology. At about $3500 \mathrm{mwd}$, the genesis of these terraces is difficult to envisage without invoking the action of a tectonic driving force. In fact, the seismic profiles and bathymetric map show evidence of active crustal deformation expressed by the presence of an arch that affects both the basement and the seafloor at a length scale of about $100 \mathrm{~km}$ (Fig. 2a and 3). Note that this width is similar to 
that of the High Atlas (Fig. 8). Moreover, the morphology of the basement bulge off Essaouira is comparable to the basement bulge along the Canary-Cape-Verde segment (Patriat and Labails, 2006; Benabdellouahed et al., 2015).

Our data suggests, that the seafloor arch off Essaouira may have formed due to a broad uplift of the basement, forming a deformation zone with a large radius of curvature, i.e. with a long wavelength, on the order of $100 \mathrm{~km}$ (Fig. 2). The key features are illustrated in Fig. 5:

- The top of the basement is structured by syn-rift block faulting which show internal unconformities indicating that the half graben structures are younger westwards;

- It was subsequently uplifted and flexed into a dome in a transpressive tectonic setting as suggested by the following observations:

- The post rift sedimentary section is also domed in a similar fashion with vertical wrenchfaulting that affects even the sea floor which indicates ongoing tectonic activity;

- The Base Upper Cenozoic unconformity cuts into underlying strata on both flanks of the dome, which indicates that the erosion is coeval with the uplift.

Considering the arch and coeval active tectonics, we suggest that the stair-case geometry of the terraces is related to an overall uplift of the region, with four possible pulses explaining the generation of the four different terraces during the late Cenozoic, as shown in the scenario proposed in (Fig. 5).

We can also try to suggest an overall rate for the tectonic uplift, however recent chronostratigraphic constraints are lacking in the region. But we showed that the deformation is recent. Therefore we calculate two possible end-member uplift rates, one considering that the terrace uplift is related to the Quaternary and another one for the Pliocene-Quaternary. Using the terraces associated with the Essaouira canyon system on the flank of our studied arch, we can estimate the approximate Pliocene-Quaternary uplift rate in this region. The height of the arch is about $830 \mathrm{~m}$ (Fig. 2). If we consider this height to represent purely 
Quaternary deformation, then the uplift rate is about $30 \mathrm{~cm} / \mathrm{kyr}$. If we include the Pliocene, it would be about $15 \mathrm{~cm} / \mathrm{kyr}$. According to (Authemayou et al., 2016; Pedoja et al., 2014) coastal uplift rates are about $5 \mathrm{~cm} / \mathrm{kyr}$ in the northwest African margin. Therefore, the uplift in our study area is at least 3 or 2 times higher. However, the uplift of the Atlantic Atlas (15 $\mathrm{cm} / \mathrm{kyr}$ ) is comparable to the rates (15 to $10 \mathrm{~cm} / \mathrm{kyr}$ ) observed in the Gibraltar Strait area (Zazo et al., 1999).

Two hypotheses can be evoked to explain the tectonic arch:

The first is that the arch was caused by sedimentary loading and the excess of density of the oceanic Jurassic lithosphere. The sediment thickness in this part of the West African margin is about 6 - 8 km (Biari et al., 2015; Klingelhoefer et al., 2016; Louden et al., 2004). The same thickness was found offshore El Jadida (Contrucci et al., 2004; Jaffal et al., 2009). Moreover, the NW Moroccan margin has the oldest oceanic lithosphere of the Atlantic, which implies an increased density. Because of this higher density, the lithosphere should have the tendency to sink in the mantle. Together, both factors might be responsible for the sagging (in the magnetic anomaly S1 area, Fig. 2b) on one side and uplift on the other side of the seabed affecting both the basement and the entire sediment sequence. The faults cross through all sedimentary layers from basement up to the seafloor (Fig. 3). In contrast, the Seine abyssal plain at 4000 mwd (SAP, Fig. 1) is characterized by a basement top, sedimentary layers and seafloor, all relatively flat-lying and is also affected by a few scattered faults, which are rare (Fig. 5abc).

In this case, the Atlantic Atlas arch and faults described here may be seen as an expression of the recent tectonic processes affecting the NW African passive margin, as observed in the Seine abyssal plain / deep offshore NW Moroccan margin (Martínez-Loriente et al., 2013). Given sufficient time this could possibly lead to subduction initiation and to the closing phase of the Wilson Cycle, as suggested for the Iberia margin (Duarte et al., 2013) or for the 
southern Tyrrhenian Sea (Billi et al., 2007). However, the degree of margin inversion in the Tafelney plateau seems to be less pronounced and at an earlier stage of evolution when compared to the Iberia margin (Duarte et al., 2013).

The profiles in Figure 5 show the arch and the existence of strong faulting in the sedimentary layers, typically reactivated normal faults, which can show either a normal or reverse sense of motion and resulting in some local folding.

Our results suggest that tectonic deformation was still active during the Quaternary. This deformation, which we define as the Atlantic Atlas tectonic arch, is interpreted to be the result of uplift of the basement (Central Atlantic rifting stage or even to the Hercynian deformations see seismic profile (Fig. 5). The uplift of the basement (syn-rift block faulting) will have generated a number of closely spaced normal faults, "piano key faults", originating from the basement and affecting the entire sedimentary sequence, as well as the seafloor (Fig.3). Additionally, the faults are basement-rooted, so that factors controlling their uplift are limited to this inheritance (Fig. 5). These geometries of the faults (piano key faults) and basement morphology indicate active tectonics, similar to structures observed in the Nekor basin (NE Morocco) by seismic imaging and bathymetric mapping (d'Acremont et al., 2014; Lafosse et al., 2016).

The second hypothesis is that the basement bulge may have formed in association with the Canary hot spot track (Duggen et al., 2009; Holik et al., 1991; Kaislaniemi and van Hunen, 2014, 2014; Mériaux et al., 2015; Neumaier et al., 2015). Indeed, a portion of the Canary plume passed seems to have passed below the lithosphere of the Atlas Mountains in North Africa towards the Alboran and Mediterranean domains crossing the study region (Duggen et al., 2009; Kaislaniemi and van Hunen, 2014). However, the migration of the Canary plume in Northwest Africa has been controversial (Berger et al., 2010). According to (Mériaux et al., 2015) deflection of Canary plume material towards the northeast below the root of the Atlas mountains is mechanically feasible. 
Based on the deformation of the basement shown in the seismic profiles (Figs. $2 b$ and 4), we suggest that overall bulge topography may have been influenced by the northward progression of hot material from the Canary plume material. Mafic igneous rocks from the Middle Atlas have trace element patterns similar to those from the Canary Islands (Duggen et al., 2009). These terraces and uplifted area are associated with the northward progression of hot material from the Canary plume material.

The reactivation of inherited Precambrian and Mesozoic rifts in response to tectonic events induced by the Africa-Europe convergence (Berger et al., 2010; Liégeois et al., 2005), played a significant role for both distribution of intraplate volcanism and uplift. According to (Mridekh et al., 2000) the western High Atlas deformation seems to have started in the Late Cretaceous and to have continued throughout the Plio-Quaternary (Fig. 7).

The anomalously high uplift rate $(15-30 \mathrm{~cm} / \mathrm{yr})$ calculated in the area could be interpreted to have resulted from the combination of two independent processes that can lead to uplift: the tectonic uplift linked to Africa-Europe convergence and the dynamic uplift related with the impingement of buoyant (Canary) plume material plume material.

Finally, we have shown in this study that the formation of these terraces and migration of the canyon (Fig. 7) is related to the active deformation of the basement and that the deep mantle structure may have played a major role in the creation of the arch observed in the bathymetry and seismic data. (Miller and Becker, 2014) showed that the impingement and circulation of plume material is necessary to explain the anomalous high topography of the Atlas Mountains, which are not isostatically compensated by a lithospheric root. The recent study of (Boulton et al., 2014) showed that uplift events can be correlated to the convective removal of the Atlas lithospheric root. Whatever the origin of the arch, there seems to be a direct relationship between the origin of the High Atlas and the arch studied in this work (Fig. 8). For this reason, we have named this tectonic arch the Atlantic Atlas (Fig. 8). This Atlantic 
Atlas which would be the NW extension of "the High Atlas of Cap Tafelney" mapped by (Hafid, 2000; Hafid et al., 2006). We also propose that the Cenozoic uplift of the Atlantic Atlas is still active and the timing of the terraces' morphogenesis is contemporaneous with its recent uplift.

\section{Conclusions}

Processing and interpretation of new and existing deep seismic data, combined with the analysis of high resolution seismic and bathymetric data reveals the existence of a basement high with morphological expression offshore Essaouira, which we propose to name the Atlantic Atlas tectonic arch. This structural high is characterized by four sequences of submarine terraces. We propose that these terraces are signs of recent and rapid uplift. According to our interpretation, this feature may be related to the impingement of plume material from the Canary Plume, which has been proposed to account for the shallow lithosphere-asthenosphere boundary underneath the Atlas mountains, located adjacent to our study area, rather than due to the passage of an hotspot $60 \mathrm{Ma}$ ago. This proposition is in good agreement with the fact that the bulge can be traced from the Canary Hotspot region towards the Atlas Mountains. The seismic data also show short wavelength faulting and folding of the sedimentary layers overlying this basement high in the segment neighboring the Atlas mountain range. Further to the south the sedimentary layers overlying the bulge show relatively minor short-wavelength deformation, which suggests that the origin of the bulge here may have resulted from the impingement of buoyant plume material from underneath. We therefore propose that short-wavelength faulting and folding of the entire sedimentary sequence in the offshore High Atlas Mountains is a result of the ongoing convergence between the African and Eurasian plates. This region may be seen as a seaward extension of 
the Atlas mountain range, which is following the structure of Tafelney Plateau, an ancient transfer zone reactivated during the opening of the Atlantic Ocean. 


\section{Acknowledgments}

We acknowledge the comments by Jean-Philippe Avouac (editor) and an anonymous reviewer. The authors thank the captain and the crew of R/V L'Atalante as well as the seismic and OBS teams. We also thank the Moroccan authorities for providing permission for the work on land and at sea. We are extremely grateful to the many colleagues (Moroccan and BGR, German, French) with whom we worked. Pre-processing and quality control of the multichannel seismic data were performed using the SISPEED software of Ifremer. Also, we would like to thank the Conseil Régional de Finistère, Ifremer and IUEM/LGO Brest University. Duarte acknowledges the financial support from the Australian Research Council through DECRA (Discovery Early Career Researcher Award) Grant DE150100326". 


\section{References}

Anahnah, F., Galindo-Zaldívar, J., Chalouan, A., Pedrera, A., Ruano, P., Pous, J., Heise, W., Ruiz-Constan, A., Benmakhlouf, M., Carlos López-Garrido, A., Ahmamou, M., de Galdeano, C.S., Arzate, J., Ibarra, P., González-Castillo, L., Bouregba, N., Corbo, F., Asensio, E., 2012. Reply to the comment by A. G. Jones et al. on "Deep resistivity cross section of the intraplate Atlas Mountains (NW Africa): New evidence of anomalous mantle and related Quaternary volcanism." Tectonics 31, TC5012. doi:10.1029/2012TC003116

Antobreh, A.A., Krastel, S., 2006. Morphology, seismic characteristics and development of Cap Timiris Canyon, offshore Mauritania: A newly discovered canyon preserved-off a major arid climatic region. Mar. Pet. Geol. 23, 37-59. doi:10.1016/j.marpetgeo.2005.06.003

Authemayou, C., Pedoja, K., Heddar, A., Molliex, S., Boudiaf, A., Ghaleb, B., Lanoe, B.V.V., Delcaillau, B., Djellit, H., Yelles, K., Nexer, M., 2016. Coastal uplift west of Algiers (Algeria): pre- and post-Messinian sequences of marine terraces and rasas and their associated drainage pattern. Int. J. Earth Sci. 1-23. doi:10.1007/s00531-016-1292-5

Babonneau, N., Savoye, B., Cremer, M., Klein, B., 2002. Morphology and architecture of the present canyon and channel system of the Zaire deep-sea fan. Mar. Pet. Geol. 19, 445467. doi:10.1016/S0264-8172(02)00009-0

Baztan, J., Berné, S., Olivet, J.-L., Rabineau, M., Aslanian, D., Gaudin, M., Réhault, J.-P., Canals, M., 2005. Axial incision: The key to understand submarine canyon evolution (in the western Gulf of Lion). Mar. Pet. Geol., The Gulf of Lions: an overview of recent studies within the French "Margins" Programme 22, 805-826. doi:10.1016/j.marpetgeo.2005.03.011 
Beauchamp, W., Allmendinger, R.W., Barazangi, M., Demnati, A., El Alji, M., Dahmani, M., 1999. Inversion tectonics and the evolution of the High Atlas Mountains, Morocco, based on a geological-geophysical transect. Tectonics 18, 163-184.

Benabdellouahed, M., Baltzer, A., Rabineau, M., Aslanian, D., Sahabi, M., Germond, F., Loubrieu, B., and Biari, Y., 2016. Slope morphologies offshore Dakhla (SW Moroccan margin): Bull. Soc. Geol. Fr., 187, no. 1, 27-39, doi: 10.2113/gssgfbull.187.1.27.

Benabdellouahed, M., Dugué, O., Tessier, B., Thinon, I., Guennoc, P., 2013. Évolution pléistocène de la Seine fluviatile préservée en Baie de Seine. Quat. Rev. Assoc. Fr. Pour Létude Quat. 267-277. doi:10.4000/quaternaire.6688

Berger, J., Liégeois, J.-P., Ennih, N., Bonin, B., 2010. Flow of Canary mantle plume material through a subcontinental lithospheric corridor beneath Africa to the Mediterranean: COMMENT. Geology 38, e202-e202.

Biari, Y., Klingelhoefer, F., Sahabi, M., Aslanian, D., 2015. Deep Crustal Structure of the North-West African Margin from Combined Wide-angle and Reflection Seismic Data (MIRROR Seismic Survey). Tectonophysics. 656, 154-174, doi: 10.1016/j.tecto.2015.06.019.

Billi, A., Presti, D., Faccenna, C., Neri, G., Orecchio, B., 2007. Seismotectonics of the Nubia plate compressive margin in the south Tyrrhenian region, Italy: Clues for subduction inception. J. Geophys. Res. Solid Earth 1978-2012 112.

Blum, M.D., Törnqvist, T.E., 2000. Fluvial responses to climate and sea-level change: a review and look forward. Sedimentology 47, 2-48. doi:10.1046/j.13653091.2000.00008.x

Bosch, D., Maury, R.C., El Azzouzi, M. 'hammed, Bollinger, C., Bellon, H., Verdoux, P., 2014. Lithospheric origin for Neogene-Quaternary Middle Atlas lavas (Morocco): Clues 
from trace elements and $\mathrm{Sr}-\mathrm{Nd}-\mathrm{Pb}-\mathrm{Hf}$ isotopes. Lithos 205, 247-265. doi:10.1016/j.lithos.2014.07.009

Boulton, S.J., Stokes, M., Mather, A.E., 2014. Transient fluvial incision as an indicator of active faulting and Plio-Quaternary uplift of the Moroccan High Atlas. Tectonophysics 633, 16-33. doi:10.1016/j.tecto.2014.06.032

Bracene, R., Bellahcene, A., Bekkouche, D., Mercier, E., de Lamotte, D.F., 1998. The thinskinned style of the South Atlas Front in central Algeria. Geol. Soc. Lond. Spec. Publ. $132,395-404$.

Bridge, J.S., Leeder, M.R., 1979. A simulation model of alluvial stratigraphy. Sedimentology 26, 617-644. doi:10.1111/j.1365-3091.1979.tb00935.x

Bridgland, D.R., Westaway, R., 2012. The use of fluvial archives in reconstructing landscape evolution: the value of sedimentary and morphostratigraphical evidence. Neth. J. Geosci. $91,5-24$.

Carracedo, J.C., Day, S., Guillou, H., Rodriguez Badiola, E., Canas, J.A., Perez Torrado, F.J., 1998. Hotspot volcanism close to a passive continental margin; the Canary Islands. Geol. Mag. 135, 591-604.

Chiang, C.-S., Yu, H.-S., Noda, A., TuZino, T., Su, C.-C., 2012. Avulsion of the Fangliao submarine canyon off southwestern Taiwan as revealed by morphological analysis and numerical simulation. $\quad$ Geomorphology $\quad$ 177-178, 26-37. doi:10.1016/j.geomorph.2012.07.011

Cirac, P., Bourillet, J.-F., Griboulard, R., Normand, A., 2001. Le canyon de Capbreton : nouvelles approches morphostructurales et morphosédimentaires. Premiers résultats de la campagne Itsas. Comptes Rendus Académie Sci. - Ser. IIA - Earth Planet. Sci. 332, 447455. doi:10.1016/S1251-8050(01)01557-9

Contrucci, I., Klingelhofer, F., Perrot, J., Bartolome, R., Gutscher, M.-A., Sahabi, M., Malod, J., Rehault, J.-P., 2004. The crustal structure of the NW Moroccan continental margin 
from wide-angle and reflection seismic data. Geophys. J. Int. 159, 117-128. doi:10.1111/j.1365-246X.2004.02391.X

d'Acremont, E., Gutscher, M.-A., Rabaute A., Mercier de Lépinay B., Poort J., Ammar A., Tahayt, A., Le Roy P., Smit J., Do Couto D., Cancouët R., Ercilla G., Gorini C., 2014. High-resolution imagery of active faulting offshore Al Hoceima, Northern Morocco. Tectonophysics, doi:10.106/j.tecto.2014.06.008.

Davison, I., 2005. Central Atlantic margin basins of North West Africa: geology and hydrocarbon potential (Morocco to Guinea). J. Afr. Earth Sci. 43, 254-274.

Deptuck, M.E., Steffens, G.S., Barton, M., Pirmez, C., 2003. Architecture and evolution of upper fan channel-belts on the Niger Delta slope and in the Arabian Sea. Mar. Pet. Geol. 20, 649-676. doi:10.1016/j.marpetgeo.2003.01.004

Dewey, J.F., Helman, M.L., Knott, S.D., Turco, E., Hutton, D.H.W., 1989. Kinematics of the western Mediterranean. Geol. Soc. Lond. Spec. Publ. 45, 265-283.

Diaz, J., Gallart, J., Villaseñor, A., Mancilla, F., Pazos, A., Córdoba, D., Pulgar, J.A., Ibarra, P., Harnafi, M., 2010. Mantle dynamics beneath the Gibraltar Are (Western Mediterranean) from shear-wave splitting measurements on a dense seismic array. Geophys. Res. Lett. 37 (18). http://dx.doi.org/10.1029/2010GL044201

Duarte, J.C., Rosas, F.M., Terrinha, P., Schellart, W.P., Boutelier, D., Gutscher, M.-A., Ribeiro, A., 2013. Are subduction zones invading the Atlantic? Evidence from the southwest Iberia margin. Geology 41, 839-842. doi:10.1130/G34100.1

Duarte, J.C., Terrinha, P., Rosas, F.M., Valadares, V., Pinheiro, L.M., Matias, L., Magalhães, V., Roque, C., 2010. Crescent-shaped morphotectonic features in the Gulf of Cadiz (offshore SW Iberia). Mar. Geol. 271, 236-249. doi:10.1016/j.margeo.2010.02.017

Duggen, S., Hoernle, K.A., Hauff, F., Kluegel, A., Bouabdellah, M., Thirlwall, M.F., 2009. Flow of Canary mantle plume material through a subcontinental lithospheric corridor beneath Africa to the Mediterranean. Geology 37, 283-286. 
El Azzouzi, M. 'hammed, Maury, R.C., Bellon, H., Youbi, N., Cotten, J., Kharbouch, F., 2010. Petrology and K-Ar chronology of the Neogene-Quaternary Middle Atlas basaltic province, Morocco. Bull. Soc. Geol. Fr. 181, 243-257. doi:10.2113/gssgfbull.181.3.243

Flood, R.D., Damuth, J.E., 1987. Quantitative characteristics of sinuous distributary channels on the Amazon deep-sea fan. Geol. Soc. Am. Bull. 98, 728-738.

Frizon de Lamotte, D., Leturmy, P., Missenard, Y., Khomsi, S., Ruiz, G., Saddiqi, O., Guillocheau, F., Michard, A., 2009. Mesozoic and Cenozoic vertical movements in the Atlas system (Algeria, Morocco, Tunisia): an overview. Tectonophysics 475, 9-28.

Frizon de Lamotte, D., Zizi, M., Missenard, Y., Hafid, M., El Azzouzi, M., Maury, R.C., Charrière, A., Taki, Z., Benammi, M., Michard, A., 2008. The Atlas system, in: Continental Evolution: The Geology of Morocco. Springer, pp. 133-202.

Fullea, J., Fernàndez, M., Afonso, J.C., Vergés, J., Zeyen, H., 2010. The structure and evolution of the lithosphere-asthenosphere boundary beneath the Atlantic-Mediterranean Transition Region. Lithos, The lithosphere/asthenosphere boundary: Nature, formation and evolutionSession EIL-03 of the International Geological Congress 120, 74-95. doi:10.1016/j.lithos.2010.03.003

Fullea, J., Fernàndez, M., Zeyen, H., Vergés, J., 2007. A rapid method to map the crustal and lithospheric thickness using elevation, geoid anomaly and thermal analysis. Application to the Gibraltar Arc System, Atlas Mountains and adjacent zones. Tectonophysics 430, 97-117. doi:10.1016/j.tecto.2006.11.003

Fullea Urchulutegui, J., Fernàndez, M., Zeyen, H., 2006. Lithospheric structure in the Atlantic-Mediterranean transition zone (southern Spain, northern Morocco): a simple approach from regional elevation and geoid data. Comptes Rendus Geosci., Quelques développements récents sur la géodynamique du Maghreb. Some recent developments on the Maghreb geodynamics 338, 140-151. doi:10.1016/j.crte.2005.11.004 
Gibbard, P.L., Lewin, J., 2009. River incision and terrace formation in the Late Cenozoic of Europe. Tectonophysics, TOPO-EUROPE: The Geoscience of coupled Deep Earthsurface processes 474, 41-55. doi:10.1016/j.tecto.2008.11.017

Gomez, F., Beauchamp, W., Barazangi, M., 2000. Role of the Atlas Mountains (northwest Africa) within the African-Eurasian plate-boundary zone. Geology 28, 775-778.

Gutscher, M.-A., Dominguez, S., Westbrook, G.K., Le Roy, P., Rosas, F., Duarte, J.C., Terrinha, P., Miranda, J.M., Graindorge, D., Gailler, A., others, 2012. The Gibraltar subduction: A decade of new geophysical data. Tectonophysics 574, 72-91.

Gutscher, M.-A., Malod, J., Rehault, J.-P., Contrucci, I., Klingelhoefer, F., Mendes-Victor, L., Spakman, W., 2002. Evidence for active subduction beneath Gibraltar. Geology 30, $1071-1074$.

Haddou, J., Tari, G., 2007. Subsalt exploration potential of the Moroccan salt basin. Lead. Edge 26, 1454-1460. doi:10.1190/1.2805765

Hafid, M., 2000. Triassic-early Liassic extensional systems and their Tertiary inversion, Essaouira Basin (Morocco). Mar. Pet. Geol. 17, 409-429.

Hafid, M., Salem, A.A., Bally, A.W., 2000. The western termination of the Jebilet-High Atlas system (Offshore Essaouira Basin, Morocco). Mar. Pet. Geol. 17, 431-443.

Hafid, M., Tari, G., Bouhadioui, D., El Moussaid, I., Echarfaoui, H., Salem, A.A., Nahim, M., Dakki, M., 2008. Atlantic basins, in: Continental Evolution: The Geology of Morocco. Springer, pp. 303-329.

Hafid, M., Zizi, M., Bally, A.W., Salem, A.A., 2006. Structural styles of the western onshore and offshore termination of the High Atlas, Morocco. Comptes Rendus Geosci. 338, 5064.

Holbrook, J., Schumm, S.A., 1999. Geomorphic and sedimentary response of rivers to tectonic deformation: a brief review and critique of a tool for recognizing subtle 
epeirogenic deformation in modern and ancient settings. Tectonophysics 305, 287-306. doi:10.1016/S0040-1951(99)00011-6

Holik, J.S., Rabinowitz, P.D., Austin, J.A., 1991. Effects of Canary hotspot volcanism on structure of oceanic crust off Morocco. J. Geophys. Res. Solid Earth 96, 12039-12067. doi:10.1029/91JB00709

Jaffal, M., Klingelhoefer, F., Matias, L., Teixeira, F., Amrhar, M., 2009. Crustal structure of the NW Moroccan margin from deep seismic data (SISMAR Cruise). Comptes Rendus Geosci. 341, 495-503. doi:10.1016/j.crte.2009.04.003

Kaislaniemi, L., van Hunen, J., 2014. Dynamics of lithospheric thinning and mantle melting by edge-driven convection: Application to Moroccan Atlas mountains. Geochem. Geophys. Geosystems 15, 3175-3189.

Khatib, J.E., Ruellan, E., Foughali, A.E., Morabet, A.M.E., 1995. Evolution de la marge atlantique sud marocaine: bassin de Tarfaya-Laayoune (Evolution of the southern Morocco Atlantic margin: Tarfaya-Laayoune Basin). Oceanogr. Lit. Rev. 9, 747.

Klingelhoefer, F., Biari, Y., Sahabi, M., Aslanian, D., Schnabel, M., Matias, L., Benabdellouahed, M., Funck, T., Gutscher, M.-A., Reichert, C., Austin, J.A., 2016. Crustal structure variations along the NW-African continental margin: A comparison of new and existing models from wide-angle and reflection seismic data. Tectonophysics 674, 227-252. doi:10.1016/j.tecto.2016.02.024

Klingelhoefer, F., Evain, M., Afilhado, A., Rigoti, C., Loureiro, A., Alves, D., Leprêtre, A., Moulin, M., Schnurle, P., Benabdellouahed, M., Baltzer, A., Rabineau, M., Feld, A., Viana, A., Aslanian, D., 2015. Imaging proto-oceanic crust off the Brazilian Continental Margin. Geophys. J. Int. 200, 471-488. doi:10.1093/gji/ggu387

Koulali, A., Ouazar, D., Tahayt, A., King, R.W., Vernant, P., Reilinger, R.E., McClusky, S., Mourabit, T., Davila, J.M., Amraoui, N., 2011. New GPS constraints on active 
deformation along the Africa-Iberia plate boundary. Earth Planet. Sci. Lett. 308, 211217. doi:10.1016/j.epsl.2011.05.048

Lafosse, M., d’Acremont, E., Rabaute, A., Mercier de Lépinay, B., Tahayt, A., Ammar, A., Gorini, C., 2016. Evidence of quaternary transtensional tectonics in the Nekor basin (NE Morocco). Basin Res. n/a-n/a. doi:10.1111/bre.12185

Lancelot, Y., Winterer, E.L., 1980. Evolution of the Moroccan oceanic basin and adjacent continental margin—a synthesis. Init Rep Deep Sea Drill. Proj. 50, 801-821.

Laville, E., Piqué, A., 1992. Jurassic penetrative deformation and Cenozoic uplift in the central High Atlas (Morocco): a tectonic model. Structural and orogenic inversions. Geol. Rundsch. 81, 157-170.

Le Roy, P., Guillocheau, F., Piqué, A., Morabet, A.M., 1998. Subsidence of the Atlantic Moroccan margin during the Mesozoic. Can. J. Earth Sci. 35, 476-493.

Le Roy, P., Piqué, A., 2001. Triassic-Liassic Western Moroccan synrift basins in relation to the Central Atlantic opening. Mar. Geol. 172, 359-381.

Le Roy, P., Sahabi, M., Lahsini, S., Mehdi, K., Zourarah, B., 2004. Seismic stratigraphy and cenozoic evolution of the mesetan moroccan atlantic continental shelf. J. Afr. Earth Sci. $39,385-392$.

Lewin, J., Gibbard, P.L., 2010. Quaternary river terraces in England: Forms, sediments and processes. Geomorphology 120, 293-311. doi:10.1016/j.geomorph.2010.04.002

Liégeois, J.-P., Benhallou, A., Azzouni-Sekkal, A., Yahiaoui, R., Bonin, B., 2005. The Hoggar swell and volcanism: reactivation of the Precambrian Tuareg shield during Alpine convergence and West African Cenozoic volcanism. Geol. Soc. Am. Spec. Pap. 388, 379-400.

Louden, K.E., Tucholke, B.E., Oakey, G.N., 2004. Regional anomalies of sediment thickness, basement depth and isostatic crustal thickness in the North Atlantic Ocean. Earth Planet. Sci. Lett. 224, 193-211. 
Louden, K., Wu, Y., Tari, G., 2013. Systematic variations in basement morphology and rifting geometry along the Nova Scotia and Morocco conjugate margins. Geol. Soc. Lond. Spec. Publ. 369, 267-287. doi:10.1144/SP369.9

Martínez-Loriente, S., Gràcia, E., Bartolome, R., Sallarès, V., Connors, C., Perea, H., Lo Iacono, C., Klaeschen, D., Terrinha, P., Dañobeitia, J.J., Zitellini, N., 2013. Active deformation in old oceanic lithosphere and significance for earthquake hazard: Seismic imaging of the Coral Patch Ridge area and neighboring abyssal plains (SW Iberian Margin). Geochem. Geophys. Geosystems 14, 2206-2231. doi:10.1002/ggge.20173

Mattauer, M., Tapponnier, P., Proust, F., 1977. Sur les mecanismes de formation des chaines intracontinentales; l'exemple des chaines atlasiques du Maroc. Bull. Société Géologique Fr. 521-526.

Medina, F., Cherkaoui, T.D., 1988. Precision sur le mecanisme au foyer du seisme d'Agadir (Maroc) du 29 Fevireier 1960. Place dans le cadre sismotectonique du Maroc. Geophysica 24, 57-66.

Mériaux, C.A., Duarte, J.C., Duarte, S.S., Schellart, W.P., Chen, Z., Rosas, F., Mata, J., Terrinha, P., 2015. Capture of the Canary mantle plume material by the Gibraltar arc mantle wedge during slab rollback. Geophys. J. Int. 201, 1717-1721.

Michard, A., Saddiqi, O., Chalouan, A., de Lamotte, D.F., 2008. Continental evolution: The geology of Morocco: Structure, stratigraphy, and tectonics of the Africa-AtlanticMediterranean triple junction. Springer.

Miller, M.S., Becker, T.W., 2014. Reactivated lithospheric-scale discontinuities localize dynamic uplift of the Moroccan Atlas Mountains. Geology 42, 35-38. doi:10.1130/G34959.1

Missenard, Y., Michard, A., Durand-Delga, M., 2008. Major steps in the geological discovery of Morocco, in: Continental Evolution: The Geology of Morocco. Springer, pp. 377-393. 
Missenard, Y., Zeyen, H., Frizon de Lamotte, D., Leturmy, P., Petit, C., Sébrier, M., Saddiqi, O., 2006. Crustal versus asthenospheric origin of relief of the Atlas Mountains of Morocco. J. Geophys. Res. Solid Earth 1978-2012 111.

Mridekh, A., Toto, E.A., Hafid, M., El Ouataoui, A., 2000. Structure sismique de la plateforme Atlantique au large d'Agadir (Maroc sud-occidental). Comptes Rendus Académie Sci.-Ser. IIA-Earth Planet. Sci. 331, 387-392.

Mulder, T., Zaragosi, S., Garlan, T., Mavel, J., Cremer, M., Sottolichio, A., Sénéchal, N., Schmidt, S., 2012. Present deep-submarine canyons activity in the Bay of Biscay (NE Atlantic). Mar. Geol. 295-298, 113-127. doi:10.1016/j.margeo.2011.12.005

Neumaier, M., Back, S., Littke, R., Kukla, P.A., Schnabel, M., Reichert, C., 2015. Late Cretaceous to Cenozoic geodynamic evolution of the Atlantic margin offshore Essaouira (Morocco). Basin Res. n/a-n/a. doi:10.1111/bre.12127

Nocquet, J.-M., 2012. Present-day kinematics of the Mediterranean: A comprehensive overview of GPS results. Tectonophysics, Orogenic processes and structural heritage in Alpine-type mountain belts 579, 220-242. doi:10.1016/j.tecto.2012.03.037

Patriat, M., Labails, C., 2006. Linking the Canary and Cape-Verde hot-spots, northwest Africa. Mar. Geophys. Res. 27, 201-215.

Pedoja, K., Husson, L., Johnson, M.E., Melnick, D., Witt, C., Pochat, S., Nexer, M., Delcaillau, B., Pinegina, T., Poprawski, Y., Authemayou, C., Elliot, M., Regard, V., Garestier, F., 2014. Coastal staircase sequences reflecting sea-level oscillations and tectonic uplift during the Quaternary and Neogene. Earth-Sci. Rev. 132, 13-38. doi:10.1016/j.earscirev.2014.01.007

Price, I., 1980. Gravity tectonics on a passive margin: Deep Sea Drilling Project Site 415 in relation to regional seismic data. Initial Rep. DSDP Wash. US Gov. Print. Off. 50, 759771. 
Roeser, H.A., Steiner, C., Schreckenberger, B., Block, M., 2002. Structural development of the Jurassic Magnetic Quiet Zone off Morocco and identification of Middle Jurassic magnetic lineations. J. Geophys. Res. Solid Earth 1978-2012 107, EPM-1.

Ruellan, E., Auzende, J.-M., 1985. Structure et evolution du plateau sous-marin de El Jadida (Mazagan, Ouest Maroc). Bull. Société Géologique Fr. 1, 103-114.

Russo, P.H., Russo, L., 1934. Le grand accident sud-atlasien. Bull Soc Géol Fr. 4, 375-384.

Sahabi, M., Aslanian, D., Olivet, J.-L., 2004. Un nouveau point de départ pour l'histoire de l'Atlantique central. Comptes Rendus Geosci. 336, 1041-1052.

Savoye, B., Cochonat, P., Apprioual, R., Bain, O., Baltzer, A., Bellec, V., Beuzart, P., Bourillet, J.-F., Cagna, R., Cremer, M., Crusson, A., Dennielou, B., Diebler, D., Droz, L., Ennes, J.-C., Floch, G., Guiomar, M., Harmegnies, F., Kerbrat, R., Klein, B., Kuhn, H., Landuré, J.-Y., Lasnier, C., Le Drezen, E., Le Formal, J.-P., Lopez, M., Loubrieu, B., Marsset, T., Migeon, S., Normand, A., Nouzé, H., Ondréas, H., Pelleau, P., Saget, P., Séranne, M., Sibuet, J.-C., Tofani, R., Voisset, M., 2000. Structure et évolution récente de l'éventail turbiditique du Zaïre: premiers résultats scientifiques des missions d'exploration Zaïango1 \& 2 (marge Congo-Angola). Comptes Rendus Académie Sci. Ser. IIA - Earth Planet. Sci. 331, 211-220. doi:10.1016/S1251-8050(00)01385-9

Spieker, K., Wölbern, I., Thomas, C., Harnafi, M., Moudnib, L.E., 2014. Crustal and uppermantle structure beneath the western Atlas Mountains in SW Morocco derived from receiver functions. Geophys. J. Int. 198, 1474-1485. doi:10.1093/gji/ggu216

Tari, G., Jabour, H., 2013. Salt tectonics along the Atlantic margin of Morocco. Geol. Soc. Lond. Spec. Publ. 369, 337-353. doi:10.1144/SP369.23

Tari, G., Molnar, J., 2005. Correlation of syn-rift structures between Morocco and Nova Scotia, Canada. Program Abstr. - Soc. Econ. Paleontol. Gulf Coast Sect. Res. Conf. 25, 9-9. 
Teixell, A., Ayarza, P., Zeyen, H., Fernandez, M., Arboleya, M.-L., 2005. Effects of mantle upwelling in a compressional setting: the Atlas Mountains of Morocco. Terra Nova 17, 456-461. doi:10.1111/j.1365-3121.2005.00633.x

Vincent, E., Cepek, P., Sliter, W.V., Westberg, M.J., Gartner, S., 1980. Biostratigraphy and depositional history of the Moroccan basin, eastern North Atlantic, Deep Sea Drilling Project leg 50. Initial Rep. DSDP Wash. US Gov. Print. Off. 50, 775-799.

Wynn, R.B., Cronin, B.T., Peakall, J., 2007. Sinuous deep-water channels: Genesis, geometry and architecture. Mar. Pet. Geol., Sinuous Deep-Water Channels: Genesis, Geometry and Architecture Sinuous Deep-Water Channels 24, 341-387. doi:10.1016/j.marpetgeo.2007.06.001

Zazo, C., Silva, P.G., Goy, J.L., Hillaire-Marcel, C., Ghaleb, B., Lario, J., Bardají, T., González, A., 1999. Coastal uplift in continental collision plate boundaries: data from the Last Interglacial marine terraces of the Gibraltar Strait area (south Spain). Tectonophysics 301, 95-109. doi:10.1016/S0040-1951(98)00217-0 


\section{Figure captions:}

Figure 1 : a) Simplified tectonic map of the Atlas Mountains of NW Africa and location of continental intraplate volcanism, Atlantic arcs, Canary hotspot (red points, Holik et al., 1991) magnetic anomaly S1 (gray polygon, Sahabi et al., 2004), evaporate basins (Michard et al., 2008) and simplified tectonic of southwest Iberia margin (Duarte et al., 2013). Location of study area (white rectangle), seismic data from Mirror cruise (black lines) and seismic data from BGR (yellow lines shows reflection profile in the Fig. 4). b) Bathymetry map offshore Essaouira and Safi acquired during the Mirror marine geophysical survey between 500 mwd to 4000 mwd. The white line on the bathymetry map (b) shows reflection profile in the Fig. 2.

Figure 2: a) VHR profile Seismic acquired during the Mirror marine geophysical survey showing position of canyon and terrace systems on the bulge morphology. b) Reflection profile acquired during the Mirror survey showing VHR profile Seismic location (for location see Fig. 1b) and seafloor and basement morphologies (bulge). Ages of reflectors are based on (Lancelot and Winterer, 1980).

Figure 3: Parallel reflection profiles and bathymetry maps showing a zoom of Zone 3 (Relief area, for location see Fig. 1) acquired during the Mirror marine geophysical survey showing

Figure 4: Location of the arch using existing reflection seismic data from BGR (Roeser et al., 2002) and the University of Texas (Holik et al., 1991). Profiles show seafloor and basement morphologies and Atlantic Atlas tectonic arch offshore Essaouira.

Figure 5: a) Seismic reflection profile in figure 2 converted to depth (vertical exaggeration $6: 1)$ b) Close-up of a portion of the seismic reflection profile and interpretation showing a normal fault and the geologic throw. 
Figure 6: Wide-angle seismic models of MIRROR Profiles 1 and 2 (Biari et al., 2015) and zooms showing arch or the basement bulge. Velocities are contoured at a $0.25 \mathrm{~km} / \mathrm{s}$ interval and black lines mark layer boundaries from the modeling.

Figure 7: Model of evolution of the terrace systems, during Pliocene-Quaternary uplift, located offshore Essaouira using VHR seismic profiles acquired during the Mirror survey. Stage 1 shows the first step before channel migration and stage 2 to 5 show channel migration and terraces morphogenesis.

Figure 8: This simplified map reveals the relationship of the Atlas with the Atlantic Ocean. We propose in this map extension offshore of High Atlas and a new geographical entity, Atlantic Atlas, bordered by the Agadir fault or offshore South Atlas Fault. Red arrows indicate velocity field in a Eurasia fixed reference frame (Koulali et al., 2011; Nocquet, 2012) and blue arrows indicate plate or block motion with respect to Eurasia (Nocquet, 2012). 




Fig. 1 


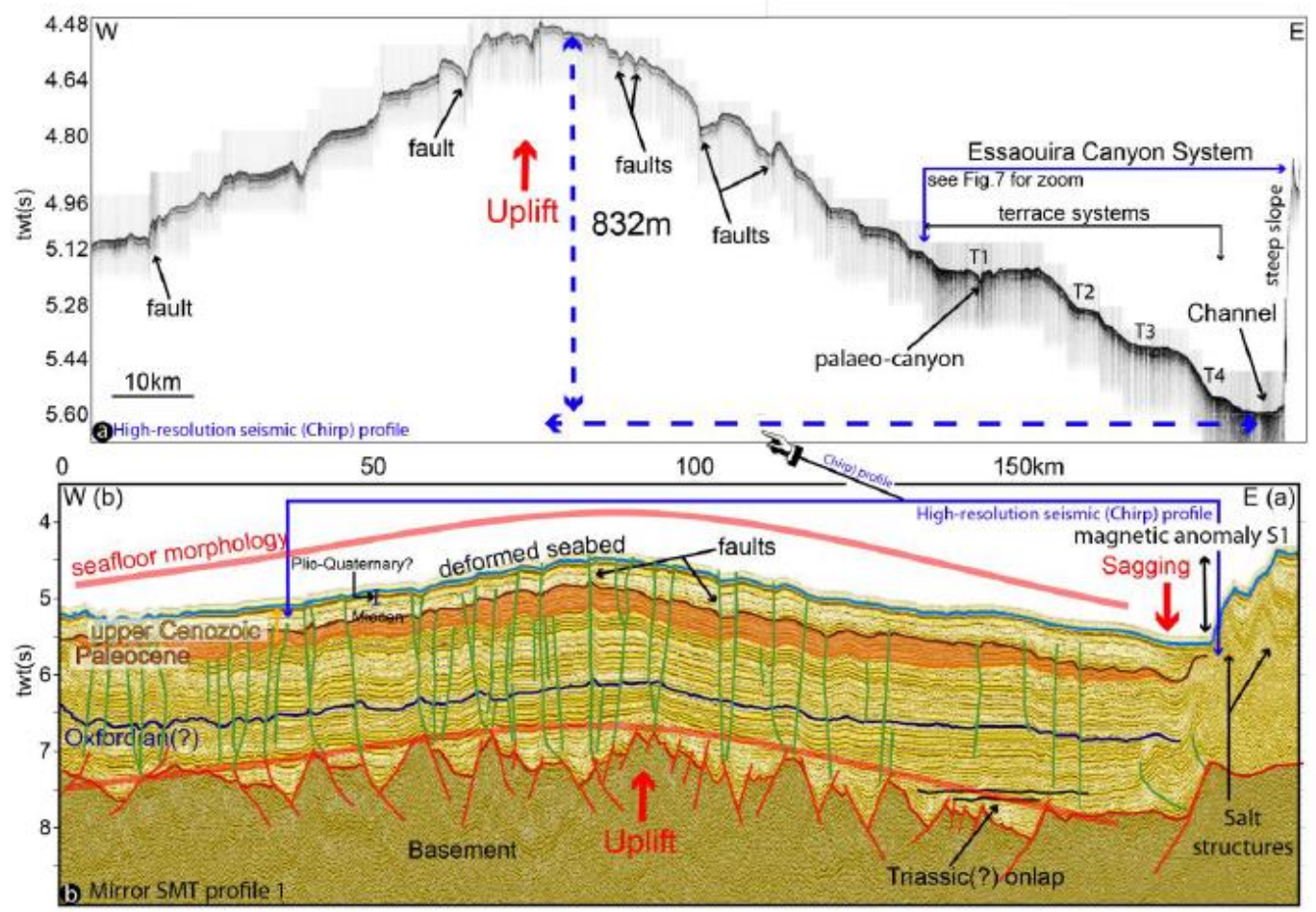

Fig. 2 

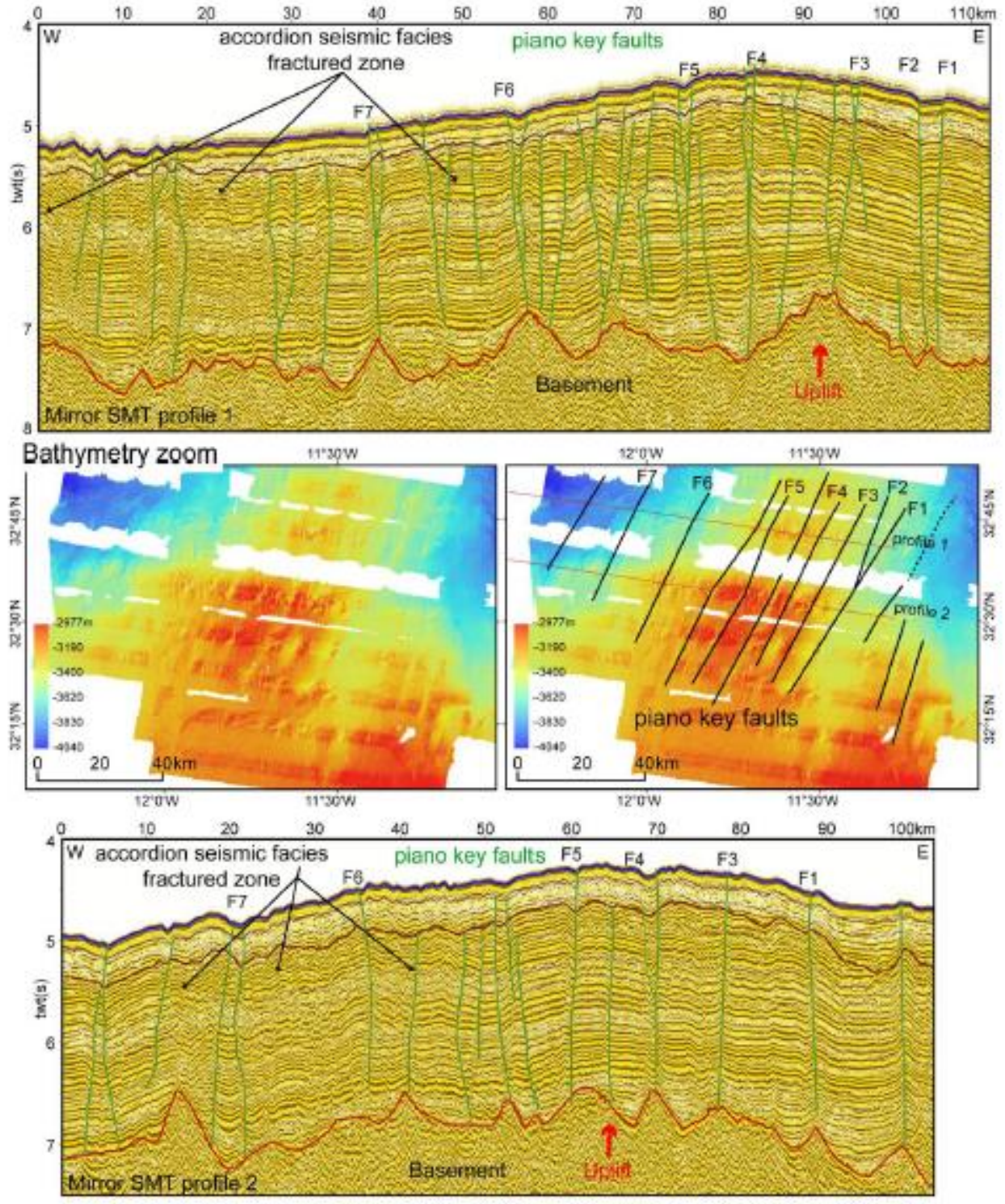

Fig. 3 


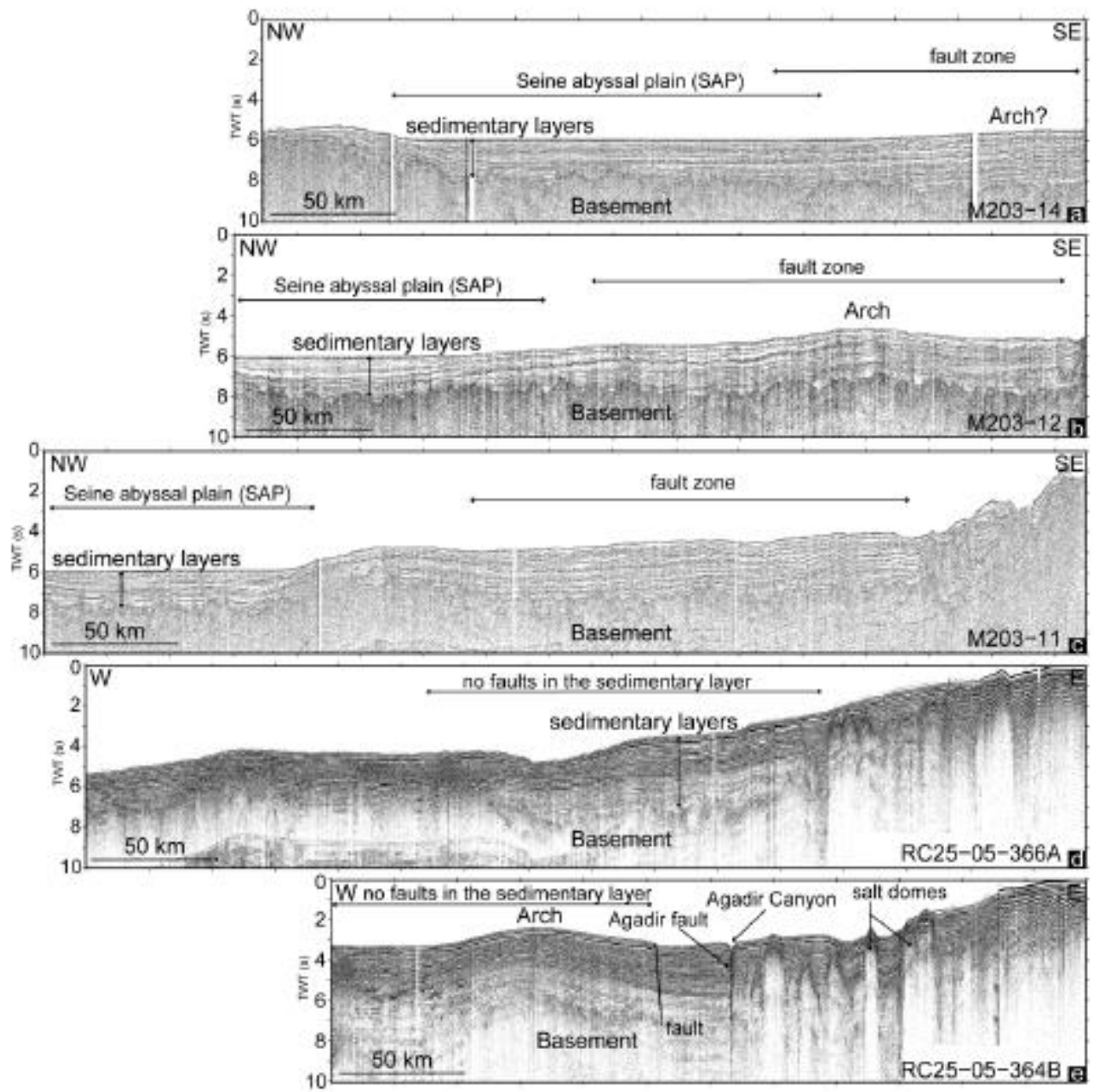

Fig. 4 


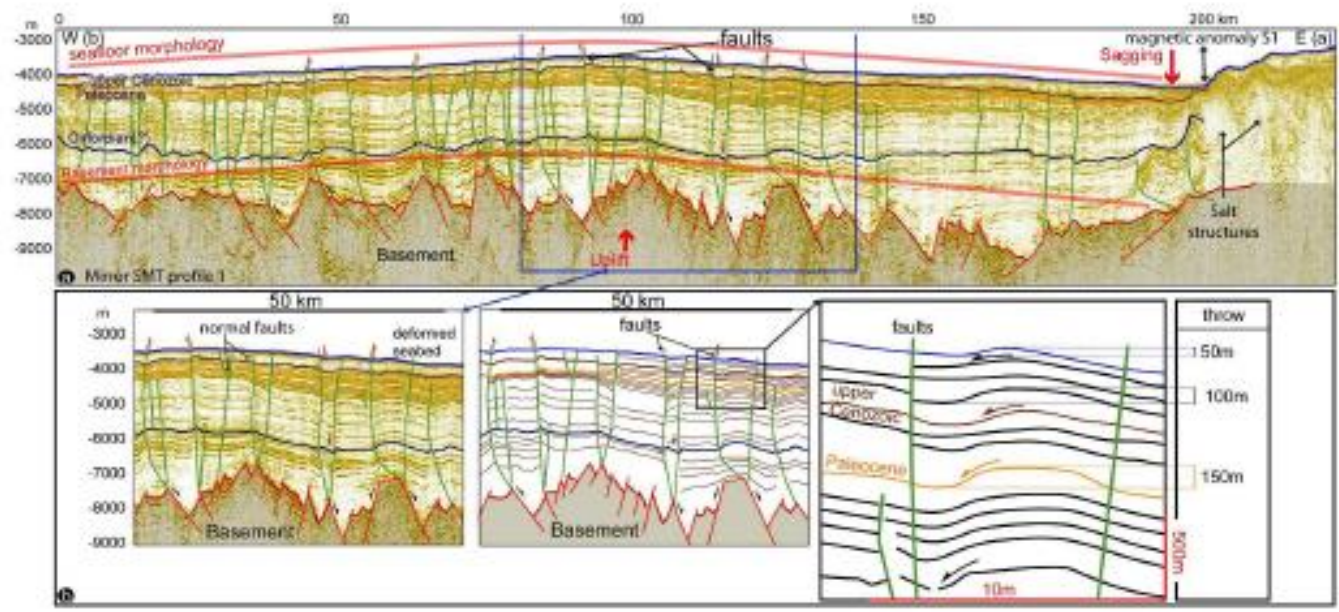




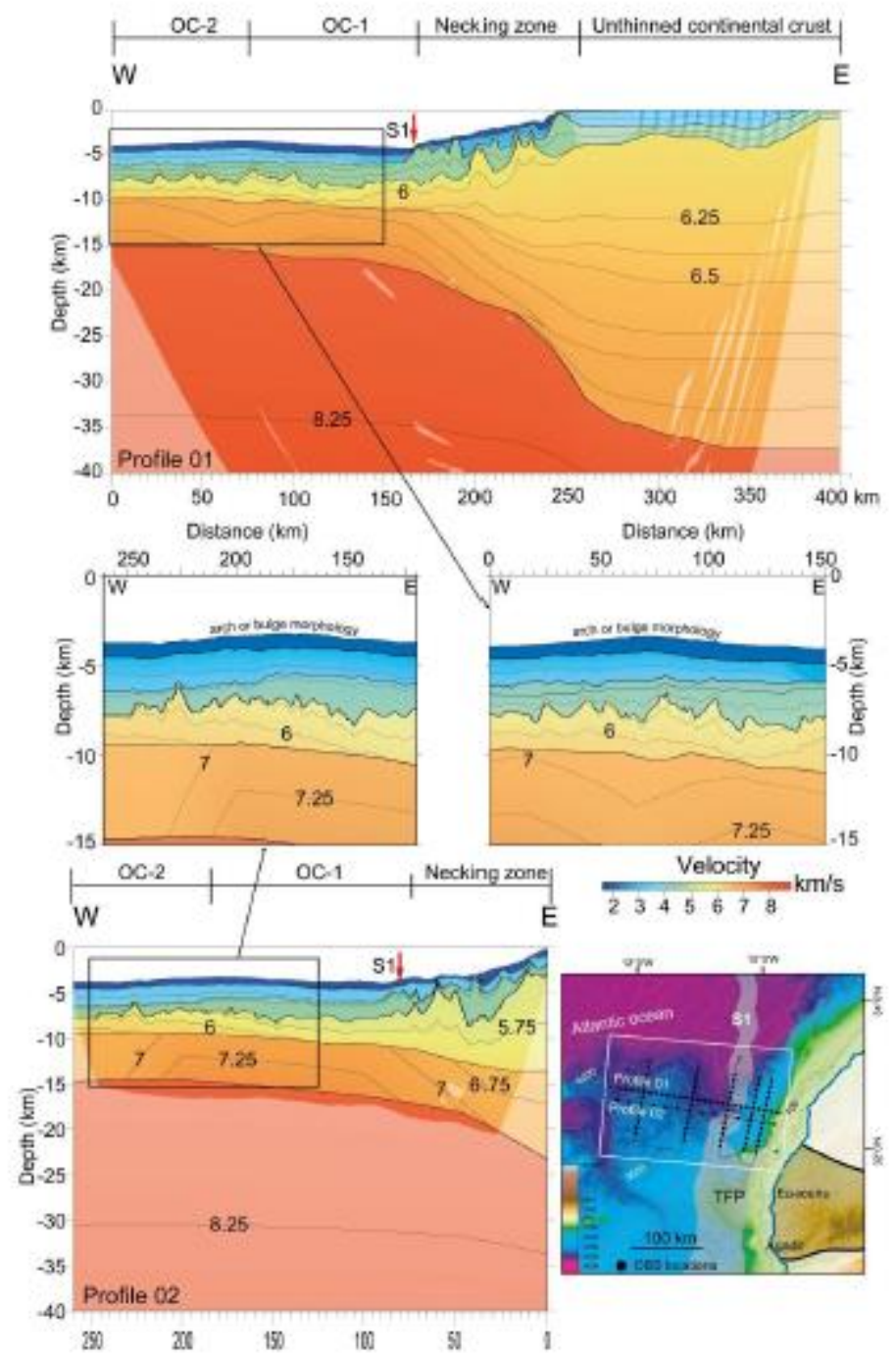

Fig. 6 


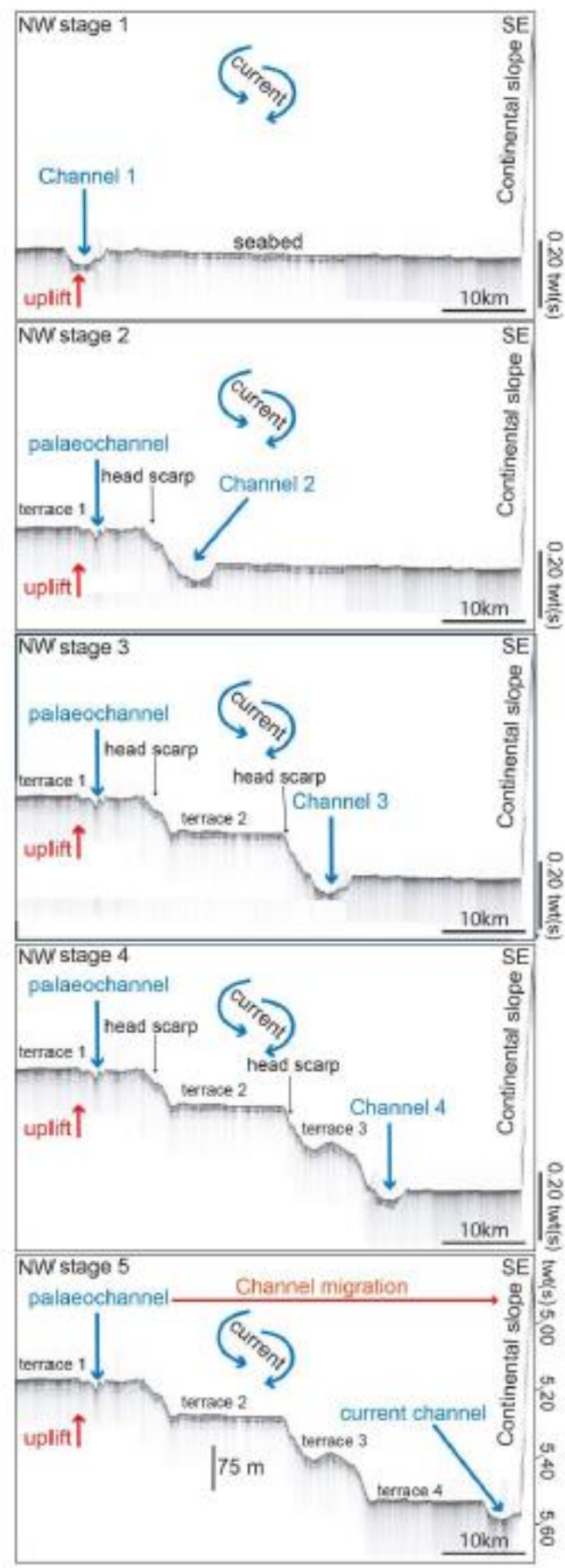

Fig. 7 


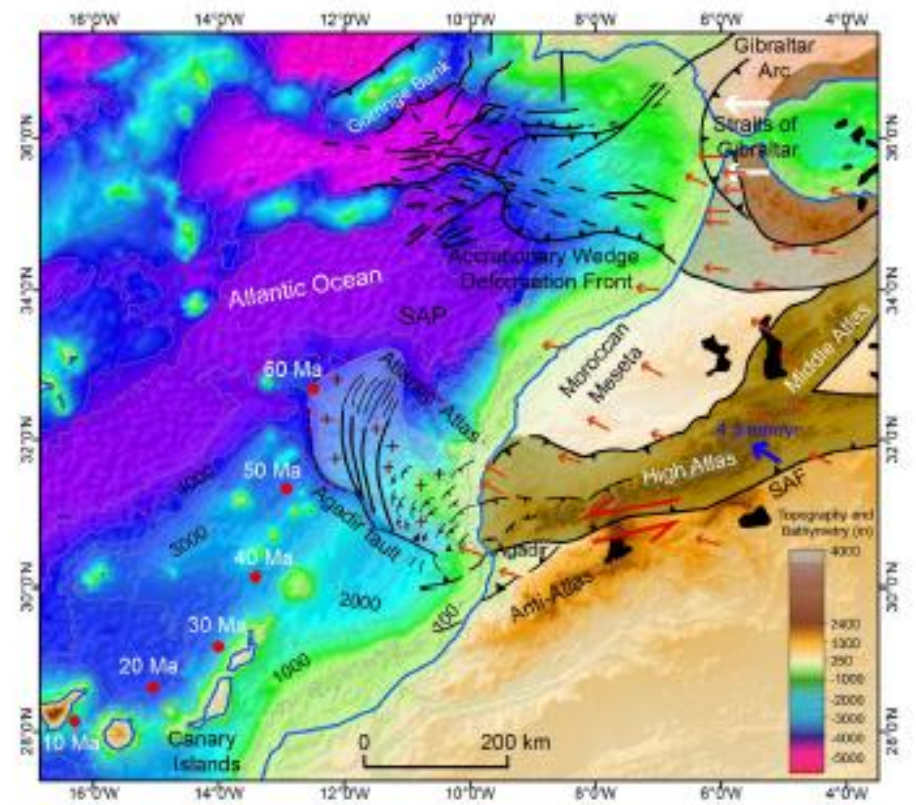

Fig. 8

\section{Highlights}

A tectonic arch called "Atlantic Atlas" has been identified offshore the High Atlas. The Atlantic Atlas is still active.

Four submarine terraces are identifiable in Atlantic Atlas (offshore Essaouira). The recent uplift is causing morphogenesis of four terraces. 